\title{
Incorporating Lean Construction agent into the Building Standards Act: the Spanish case study
}

DOI 10.1515/otmcj-2016-0010

Received October 7, 2016; accepted November 10, 2016

Abstract: There is a demand for lean construction in Europe; even though lean construction is still an emerging field and there is growing interest, there are no regulations on this topic. The main objective of this research is to regulate this role when in a project and to define and develop a building agent structure, according to the Building Standards Act (LOE by its acronym in Spanish), to be able to incorporate it into the Spanish law, protecting it from civil liabilities. In Spain, there is jurisprudence in civil jurisdiction based on the LOE to acquit or convict building agents, who are defined in the courts as "constructive managers" or similar. For this reason, courts could establish in the future several liabilities for the lean construction specialist and other agents of the project, depending on their actions and based on the implementation of the lean project delivery system, the target value design and the integrated project delivery. Conversely, it is possible that the level of action of the lean construction specialist may comprise design management, construction management and contract management. Accordingly, one or more building agents should be appropriately incorporated into the LOE according to their functions and responsibilities and based on the levels of action of the lean construction specialist. The creation of the following agents is proposed: design manager, construction manager and contract manager, definitions that are developed in this study. These agents are loosely defined, because any project manager, building information modeling manager or similar may act as one or as more-than-one of them. Finally, the creation of the lean construction manager is also proposed, as the agent who takes on the role of the design manager, construction

*Corresponding author: Xavier Brioso, Construction Management \& Technology Research Group (GETEC), Pontifical Catholic University of Peru, Avenida Universitaria 1801, Lima 32, Peru, Tel. +51 16262000 , E-mail: xbrioso@pucp.edu.pe

Antonio Humero, School of Architecture, Technical University of Madrid, Spain, Avenida Juan de Herrera, 4, 28040 Madrid, Spain manager and contract manager, but focused on the lean production principles.

Keywords: construction manager, contract manager, design manager, lean construction, regulation

\section{Introduction}

\subsection{Lean production and lean construction}

The Toyota Production System (Lean Production) designed cars based on specific requests by its clients and made significant effort to reduce the time it takes to set up the machine and improve the quality management. It also developed three desired outcomes for the production system: to provide the customer with the highest-quality vehicle that also satisfies the customer in every way; to reduce response time and define a "just-in-time" approach; and to supply what is needed when it is needed and thereby eliminate waste (Howell and Ballard 1998). These outcomes were planned in an environment that encourages collaboration between the company itself and independent suppliers based on prior agreements that are, in practice, collaboration contracts.

Since Koskela published his technical report TR72 in 1992, giving rise to lean construction, application of this trend has evolved (Brioso 2015). According to Koskela (1992), due to traditional management principles, flow processes have not been controlled or improved in an orderly fashion; this has led to complex, uncertain and confused flow processes; expansion of non-value-adding activities; and reduction of output value. Koskela (1992) defined lean construction as "a way to design the production system to minimize the waste of material, time and effort, in order to generate the maximum amount of value". He also mentions that the information and the flow of material, as well as the method of operation in design and construction, have to be measured based on waste and their added value. 


\subsection{Last Planner System}

The Last Planner ${ }^{\circledR}$ System (LPS) is derived by combining the central elements of task management and flow management to control production in all areas of construction, thereby improving performance (Koskela 1999). LPS is a production planning system designed to produce predictable workflow and fast learning in terms of programming, design, construction and commissioning of projects (Tsao et al. 2014). LPS has been in development by Glenn Ballard since 1992 (Ballard 2000a) and has five elements: (1) master scheduling; (2) phase scheduling; (3) make work ready planning; (4) weekly work planning and (5) learning (Ballard 2000a). The AEC industry has used the terms "Pull Planning", "Phase Scheduling", "Reverse Phase Scheduling", and "Phase Planning" interchangeably (Tsao et al. 2014).

\subsection{Lean project delivery system}

In 2000, Ballard (2000b) stated that the lean project delivery system (LPDS) emerged from theoretical and practical investigations and was in a process of ongoing development through experimentation in many parts of the world.

In recent years, experiments have focused on the definition and design phase of projects, applying concepts and methods drawn from the Toyota Product Development System, most especially target costing and set based design. ... it is necessary to understand customer purpose and constraints expose the customer to alternative means for accomplishing their purposes beyond those they have previously considered, and to help customers understand the consequences of their desires. This process inevitably changes all the variables: ends, means and constraints. (Ballard 2008).

\subsection{Target value design and integrated project delivery}

Target Value Design (TVD) is a disciplined management practice to be used throughout project to assure that the facility meets the operational needs and values of the users, is delivered within the allowable budget, and promotes innovation throughout the process to increase value and eliminate waste. Target Cost is the cost goal established by the delivery team as the "target" for its design and delivery efforts. (LCI Lean Project Delivery Glossary 2014).

Integrated project delivery (IPD) is a project delivery approach that integrates people, systems, business structures and practices into a process that collaboratively harnesses the talents and insights of all participants to reduce waste and optimize efficiency through all phases of design, fabrication and construction (American Institute of Architects 2007). IPD is an approach of relational contracting, focusing on the main objectives of the projects and the major stakeholders and developing an organization capable of applying the principles and main practices of LPDS (Matthews and Howell 2005). The team is invited to participate within a flexible contractual management framework, aimed at building win-win relationships of trust. Once the team accepts the invitation, it starts interacting through a collaborative routine in which building information modeling (BIM) tools are used, which in turn allow the analysis of each alternative posed by the stakeholders, seeking not to exceed the target cost of each stakeholder in the event that adjustments are required. IPD, target value design (TVD) and BIM are used simultaneously (Brioso 2015).

\subsection{Regulating lean construction}

"Project and Construction Management" is a practice with international recognition, regulated in the United States, as well as in the United Kingdom, France and Germany (Soler 2012). However, each country has contractual restrictions as set in current legislation, with reference to the different types of projects, procedures, contract models and forms original to each country or state, or developed to an extent, according to the kind of the construction. The "lean construction" agent is internationally renowned, not yet regulated, and is very much "in" all over the world, in countries such as the United States, the United Kingdom, Brazil, Australia, France, Germany, Chile and Peru, among others. However, depending on each country's regulation, its responsibilities can overlap with those of other specialists focused mainly on design or the project's execution. The main objective of this research is to standardize the lean construction agent within the Building Standards Act (Ley de Ordenación de la Edificación, LOE by its acronym in Spanish) in Spain. This could also work in other countries, in Europe or other parts of the world that are in a much similar situation at the moment.

\section{Spanish regulation and jurisprudence in civil jurisdiction}

According to Humero (2015), the LOE (1999), as per the results of a long-term experience process, garners only 
figures that have been appearing in the construction sector since the final draft of the Civil Code (1974) in the late twentieth century; therefore, the LOE does not consider other international movements and trends that have been included in this area, such as project manager, facility manager, construction manager, safety manager, risk manager, design manager and others, disregarding the need for a continuous upgrade of the law to adapt to the changing reality of the current state of the field. Because there does not exist any type of regulation in Spain regarding the agent in lean construction, contracts can be made defining such a special kind of agent in construction. The lean construction specialist is hired by other agents who deal in areas similar and related to "Project and Construction Management”, and both agents' responsibilities can overlap even if they were designated as construction manager or design manager. Because of the number of advisers, specialists and agents who participate in the design and execution of the construction process, it is necessary for regulation for these agents as and when they participate in each stage of the project. Conversely, there is jurisprudence from the Supreme Court (Poder Judicial de España 2015) that might serve as a legal base to establishing a specific regulation within the LOE for the Project and Construction Management agent (Soler 2012). This agent, too, can be considered as the lean construction agent.

\section{Methodology}

\subsection{LOE analysis}

Requirements are analyzed for all the different agents who participate in the construction process, from which we can derive their responsibilities. We also analyze the Spanish Civil Code and the doctrines that still apply. The agents detailed in the LOE include the safety and health coordinators, active both during the elaboration of the safety and health study as well as during the execution of the building.

\subsection{Lean construction agent analysis}

It is important to note that in the Spanish market, the lean construction and BIM specialists do exist as such (Pellicer 2015). We proceed to analyze the different meanings and impacts that the lean construction specialist has, according to the term's evolution.

\subsection{Jurisprudence analysis}

Jurisprudence on the construction manager was examined, as dictated by the Supreme Court of Justice, and it might even "reach" or "absorb" the lean construction specialist. To obtain the jurisprudence, searches were conducted in Spain's Judiciary's Web site (Poder Judicial de España 2015), in the Supreme Court of Justice section, using keyword combinations such as "Building Standards Act", "constructive manager", "construction manager" and "design manager", among others. Under the label "constructive manager", which is an interpretation of Article 1591 of the Civil Code (1974), the Supreme Court has already dictated the civil responsibility for agents who, in all manners, function as project managers or similar, which is in direct relation to LOE indication and is further detailed in the following section.

\section{Results and discussion}

\subsection{LOE analysis}

For all different agents who participate in the construction process, all obligations are detailed and accounted for, through which we can conclude their responsibilities, detailing the building contractor as the person or company that guarantees the movement of the whole process and who is responsible for the quality and the material damage that the building might sustain. Within the scope of the building contractor's activities and responsibilities, the onsite manager has a special role, as well as the obligation of ensuring that all subsequent contracts are made within the law. The framework of the law also defines the behavior expected of agents, such as the project designer, the owner of the site and the execution manager, confirming their responsibilities. There are other agents also related to those earlier indicated in the LOE, who are defined in Article 2 of the Royal Decree 1627/1997 regarding Construction Site Safety and Health (1997), mainly the Safety and Health Coordinator during the elaboration of the project and the Safety and Health Coordinator during the execution of the project.

LOE's Article 17 defines that the legal responsibility of the different agents for property damage liability in a building would be personal, meaning the focus is on one agent, based on their own actions or on the action of someone else that such person is responsible for. Joint liability would be required when responsibility for such actions cannot be narrowed down to one person, 
or when liability is due to the actions of more than one agent, or if such responsibility is in any way shared by those agents (LOE 1999). LOE's Seventh additional disposition, Sue notification request for other agents (LOE 1999), speaks of the "third party intervention principle in legal proceedings, requested by the defendant", indicating that "a person who might end up sued as a result of actions or liability based on the obligations of their intervention of the construction process, and purview in the present law, might request, within the time limit the Civil Prosecution Law grants to answer the sue, to notify one or more agents that had intervened in such process". Regarding the liability time limits, they are set in groups of one, three and ten years, depending on the different types of damage caused to the construction. The building contractor, during the first year, is responsible for all material damages done to the building because of poor execution; every agent who intervened in the project would be liable (i) for up to three years for damages to the building caused by latent defect or defects that affect the building and (ii) for up to ten years, for damages resulting from latent defect or defects that affect the building's structural integrity.

Conversely, in Article 1, Section 6, the Spanish Civil Code indicates that the jurisprudence will complement the judicial order with the doctrine that the Supreme Court might establish interpreting or applying the law, practice and general principles of the law (Civil Code 1974). This means that the Supreme Court is the highest authority in applying the jurisprudence, based on the lack of the specific judicial order.

\subsection{Analysis of the lean construction agent}

When the lean construction persona appears, as has been happening in many countries where the trend has taken over, this agent is usually an outside consultant of the owner, different from the agents already included in the law and to the Project Manager, who advises on the organization of the construction work and the application of the principles, tools and system techniques. Likewise, he or she can advise the owner in any phase of the project, in the design management, contract management, and material execution management; therefore, they are figures who have functions and related tasks that, many times, overlap with those of the project manager and other agents. When the first evolution of lean construction happens, including in the LPDS, an additional figure is created, whom we can define as the design manager, who participates in the project's definition and lean design phase, including adopting the tools, techniques and practices of this philosophy to design the project, ensuring that the needs and requirements of the stakeholders are considered in the design alternatives, selecting the alternative that best suits the purpose and needs of the project, as well as including the lean construction practices from the initial phases. As a second evolution of the lean construction philosophy occurs, creating the TVD-IPD, a new figure appears that we could name in a general way as the contract manager. This agent, as requested by the owner, collaborates with him in the construction project management, focused on optimizing the contract management in all the phases of the project, in a way that such contracts are full collaboration activities. This agent runs and manages the other agents' contract processes in all the phases of the construction project. Finally, we the lean construction agent can be created, and they take upon themselves the design management, the construction management and/or the contract management, as per the needs of the project.

\subsection{Jurisprudence analysis}

We searched and analyzed in the jurisprudence about constructive managers, as dictated by the Justice Supreme Court, which could "reach" or "absorb" the new construction agent, the lean construction specialist. To obtain the jurisprudence, we conducted a search in Spain's Judiciary's Web site (Poder Judicial de España 2015), in the Justice Supreme Court section, and we used the combination of keywords such as "Building Standards Act", "constructive manager", "construction manager" and "design manager", among others, obtaining a statistical population of 186 samples, of which only 17 were considered most important for being the closest related with the possible figures of the lean construction specialist, which could be determined by the Supreme Court. Table 1 shows the summary of the analysis.

As noted in Section 4.1, LOE Analysis, the Seventh Section (1999) leaves open the possibility that, the agents who might be indicted, among them the owner, the building manager, the project manager, the construction manager, the onsite manager, the health and safety manager during the design of the project, the onsite health and safety manager as well as the onsite manager, might request - during the time frame that the Persecution Civil Law (2000) grants to answer this sue - that they might notify one or more agents who might have intervened in such process. Evidently, in case the lean construction agent might not be initially charged as being responsible 
Table 1: Commentaries on Supreme Court's main rulings on constructive managers

\begin{tabular}{|c|c|c|c|}
\hline No. & Codes & Content & Comments \\
\hline 1 & STS $1256 / 2004$ & $\begin{array}{l}\text { Constructive manager's liability regarding his } \\
\text { actions as site manager }\end{array}$ & $\begin{array}{l}\text { The lean construction specialist works directly with all } \\
\text { other specialists and could be confused in that way. }\end{array}$ \\
\hline 2 & STS $2071 / 2001$ & $\begin{array}{l}\text { Constructive manager's liability as he coordinated, } \\
\text { supervised technical matters and made decisions } \\
\text { on site. }\end{array}$ & The lean construction specialist can perform in this area. \\
\hline 3 & ATS $5879 / 2011$ & $\begin{array}{l}\text { Constructive manager's liability as he participated } \\
\text { in other agent's functions. }\end{array}$ & $\begin{array}{l}\text { The lean construction specialist interacts with other } \\
\text { specialists. }\end{array}$ \\
\hline 4 & STS $2676 / 2009$ & $\begin{array}{l}\text { Responsible as cooperative manager, or owner } \\
\text { manager, or similar }\end{array}$ & $\begin{array}{l}\text { The lean construction specialist can be included in this } \\
\text { area, if he were part of the project from the beginning. }\end{array}$ \\
\hline 5 & STS $1726 / 2015$ & $\begin{array}{l}\text { Free of responsibility as cooperative manager or } \\
\text { owner manager or similar. }\end{array}$ & $\begin{array}{l}\text { The lean construction specialist could be included in this } \\
\text { area if he were part of the project from the beginning. }\end{array}$ \\
\hline 6 & STS $4524 / 1994$ & $\begin{array}{l}\text { Absolved of all responsibility for construction } \\
\text { defects. }\end{array}$ & $\begin{array}{l}\text { The lean construction specialist interacts with other } \\
\text { specialists and could initially be included in this area. }\end{array}$ \\
\hline 7 & STS $4650 / 1979$ & $\begin{array}{l}\text { Responsible for damages to third parties and large } \\
\text { losses and for interrupted electric supply. }\end{array}$ & $\begin{array}{l}\text { The lean construction specialist interacts with other } \\
\text { specialists and could be included in this area. }\end{array}$ \\
\hline 8 & STS $5950 / 2009$ & $\begin{array}{l}\text { Responsible for damages in the delayed } \\
\text { completion date of the apartments, and all those }\end{array}$ & $\begin{array}{l}\text { The lean construction specialist interacts with other } \\
\text { specialists and could be included in this area. }\end{array}$ \\
\hline
\end{tabular}
agents who participated in the project should be sued equally, in order to correct all damages. unexpected settlement of the neighboring building, of one or more owners, or similar Responsibility for latent defect or construction defects.

11 STS 8112/2007 Responsibility for damages in terms of the delay of completion date, and all parties should be equally liable pending correction of all damages.

12 STS $8151 / 200$ Responsibility for latent defect or construction defects.

13 STS 8710/2007 Absolved of all responsibility under the name of manager, cooperative manager, or owner manager or similar.

14 ATS 756/1998 Responsibility for latent defect or construction defects.

15 ATS $960 / 2007$ Responsibility as cooperative manager, or owner manager or similar.

16 ATS $1769 / 201$ Responsibility for latent defect or construction defects.

17 ATS 4007/2014 Responsibility as cooperative manager, or owner manager or similar.

The lean construction specialist interacts with other specialists and could be included in this area.

The lean construction specialist interacts with other specialists and could be included in this area.

The lean construction specialist interacts with other specialists and could be included in this area.

The lean construction specialist interacts with other specialists and could be included in this area.

The lean construction specialist interacts with other specialists and could be included in this area.

The lean construction specialist interacts with other specialists and could be included in this area.

The lean construction specialist interacts with other specialists and could be included in this area.

The lean construction specialist interacts with other specialists and could be included in this area.

The lean construction specialist interacts with other specialists and could be included in this area.

in the building process, it is very likely that one of the other agents might request he be indicted as well, because he will have advised them on "alternative solutions" than those they were used to.

\subsection{Incorporation of the lean construction agent proposal}

In this investigation, we have established that the lean construction agent's influence in the design, as per LPDS, TVD or IPD, as well as in the execution itself, can overlap with that of other agents such as the design manager, site manager, construction manager, and safety and health manager during the design of the project, safety and health manager during construction as well as the onsite manager. Considering that the jurisprudence shows that the law has previously held the constructive managers liable, a figure much similar to that of the project manager, due to the fact that the lean construction professional acts alone or in association with them, it is understandable that because their responsibilities are not quite clear, the court might find the lean construction professionals also liable for such work. 
Thus, we propose the following construction agents to be added in the LOE:

- The design manager: the operative agent who, as requested by the owner and working based on the technical standard, should work alongside the owner in the coordination and management of other agents.

- The construction manager is the chosen agent who, as requested by the owner and working based on the technical standard, works alongside the owner on managing the site manager, execution manager, the onsite health and safety manager and the onsite manager.

- The contract manager is the chosen agent who, as requested by the owner and working based on the technical standard, works alongside the construction and project manager, with the purpose of improving the contract management in all areas or project stages.

None of these agents are held accountable, in any way or form, in Article 19 of LOE, Guarantees in case of compensatory damage for construction defects. Under no circumstances their actions are to overlay with that of other agents, especially those of the design manger, site manager, execution manager, health and safety manager during the project design, health and safety manager during the execution of the project and onsite manager. These agents will decide, finally, if the advice given will be taken into account in their actions, under their own responsibility.

\section{Conclusions}

The duties of the lean construction agent might overlap with those of the design manager, responsible for the execution of the project, and even with those of the safety and health project manager. It is of vital importance to regulate this agent, because the agent's responsibilities can be easily mistaken by those of other agents in the construction business. It is of main importance to regulate the construction process, by updating and filling in the legal configuration of the agents who intervene in all aspects, separating their obligations in a way that helps us to define their responsibilities without a shadow of doubt, based on a clear definition of a building's basic requirements. In Spanish jurisprudence, we have been able to define some rulings that speak of the constructive manager, an agent not yet regulated and who has a combination of functions and obligations already regulated by the LOE to other agents under their own name. In this article, we have confirmed that the agent named constructive manager, defined in jurisprudence, will broaden due to the diversity of agents that start surfacing in all aspects of a project. Considering everything explained herein, it is of vital importance that the lean construction agent be regulated, in accordance with the positions of design manager, construction manager and contract manager, in the Spanish standards with reference to the legal void it holds now.

\section{References}

American Institute of Architects. (2007). Integrated Project Delivery: A Guide, v.2. AIA National/AIA California Council, California, USA.

Ballard, G. (2000a). The Last Planner System of Production Control, Ph.D. Dissertation, School of Civil Engrg., Univ. of Birmingham, U.K., May, p. 192.

Ballard, G. (2000b). Lean Project Delivery System. White Paper \#8, Lean Construction Institute.

Ballard, G. (2008). The lean project delivery system: An update. Lean Construction Journal, 2008 Issue, pp. 1-19.

Brioso, X. (2015). Integrating ISO 21500 guidance on project management, lean construction and PMBOK. Procedia Engineering, 123, pp. 76-84.

Código Civil, Real Decreto de 24 de julio de 1889. (1974). actualizado el 09 de julio de 1974, en vigor a partir del 29/07/1974. Boletín Oficial del Estado, Madrid, España.

Howell, G., \& Ballard, G. (1998). What kind of production is construction?. In: 6th Annual Conference of the International Group for Lean Construction. Guaruja, Brazil, 13-15 Aug 1998. Guaruja, Brazil: International Group for Lean Construction.

Humero, A. (2015). Arquitectura Legal, 2da Edición. Mairea Libros, España, Madrid, 2015.

Koskela, L. (1992). Application of the New Production Philosophy to Construction, CIFE Technical Report \#72. Department of Civil Engineering, Stanford University, Stanford, USA.

Koskela, L. (1999). Management of production in construction: A theoretical view. In: 7th Annual Conference of the International Group for Lean Construction. Berkeley, USA, 26-28 Jul 1999. California, USA: International Group for Lean Construction, pp. 241-252.

LCI Lean Project Delivery Glossary. (2014). Lean Construction Institute. Available at http://www.leanconstruction.org on 14 January, 2015.

Ley 38/1999, de 5 de Noviembre. (1999). Ley de Ordenación de la Edificación. Boletín Oficial del Estado, Madrid, España.

Ley $1 / 2000$, de 7 de enero. (2000). de Enjuiciamiento Civil. Boletín Oficial del Estado, Madrid, España.

Matthews, O., \& Howell, G. (2005). Integrated Project Delivery an Example of Relational Contracting. Lean Construction Institute. Available at http://www.leanconstruction.org on 30 April, 2014.

Pellicer, E. (2015). Spanish Group for Lean Construction vía LinkedIn. Available at https://www.linkedin.com on 22 September, 2015.

Poder Judicial de España (2015). Available at http://www. poderjudicial.es/cgpj/es/Poder_Judicial on 15 September, 2015. 
Real Decreto 1627/1997, de 24 de octubre. (1997). sobre disposiciones mínimas de seguridad y de salud en las obras de construcción. Boletín Oficial del Estado, Madrid, España.

Soler, M. (2012). El Análisis de la Dirección Integrada de Proyectos (Project \& Construction Management) en el marco europeo: propuesta de regulación en España y su inclusión en la Ley de la Ordenación de la Edificación. Tesis Doctoral,
Escuela Técnica Superior de Arquitectura, Universidad Politécnica de Madrid, España.

Tsao, C. C., Draper, J., \& Howell, G. A. (2014). An overview, analysis, and facilitation tips for simulations that support and simulate pull planning. In: 22nd Annual Conference of the International Group for Lean Construction. Oslo, Norway, 25-27 Jun 2014. Oslo, Norway: International Group for Lean Construction, pp. 1483-1494. 